ISSN: 1829-6750 Inovasi Kurikulum, Agustus 2009, Thn. 6 . Vol 6 Nomor: 2

\title{
KEBUTUHAN PROGRAM MUSYAWARAH GURU MATA PELAJARANPENDIDIKAN AGAMA ISLAM UNTUK MENINGKATKAN PROFESIONALISME GURU
}

\section{Nana Husna}

Abstrak: Penelitian ini dilatarbelakangi adanya tuntutan peningkatan profesiomalisme guru pendidikan agama Islam khususnya guru pendidikan agama Islam SMP dengan pengoptimalisasian kiprah musyawarah guru mata pelajaran. Kenyataan di lapangan musyawarah guru mata pelajaran belum dapat meningkatkan profesionalisme guru pendidikan agama Islam SMP khususnya di Kabupaten Ciamis. Dengan demikian untuk dapat meningkatkan profesionalisme guru PAI SMP perlu adanya kesadaran dari para guru PAI SMP untuk dapat terus menerus meningkatkan wawasan secara rutin melalui MGMP PAI seiring dengan perkembangan ilmu pengetahuan dan teknologi. Penelitian ini bertujuan untuk memperoleh gambaran perencanaan program MGMP yang dapat menjawab kebutuhan guru PAI guna meningkatkan profesionalismenya. Metode penelitian yang dipergunakan adalah deskriptif kualitatif dengan studi kasus pada MGMP PAI SMP di Kab. Ciamis.

Kata Kunci: MGMP (Musyawarah Guru Mata Pelajaran), PAI (Pendidikan Agama Islam) dan profesionalisme

kerangka dasar dan struktur

Dedi Supriadi (1998 : 97) mengungkapkan bahwa mutu pendidikan bukan hanya dipengaruhi oleh guru, melainkan oleh mutu masukan (siswa), sarana, faktor instrumen lainnya. Tapi semua itu pada akhirnya tergantung kepada mutu pengajaran, dan mutu pengajaran tergantung pada mutu guru. Berkaitan dengan eksisitensi dan urgensi pendidikan agama Islam, Mulyasa ( 2006 : 47 ) mengungkapkan bahwa dalam kurikulum, terdapat kelompok mata pelajaran agama, lebih lanjut Mulyasa menjelaskan bahwa akhlak mulia dimaksudkan untuk membentuk peserta didik menjadi manusia yang beriman dan bertakwa kepada Tuhan Yang Maha Esa serta berakhlak mulia Akhlak mulia mencakup etika, budi pekerti, atau moral sebagai perwujudan dari pendidikan agama.

Berkaitan dengan pendidikan agama diperjelas oleh Peranturan pemerintah nomor 55 tahun 2007 
ISSN: 1829-6750 Inovasi Kurikulum, Agustus 2009, Thn. 6 . Vol 6 Nomor: 2

Pasal 2 mengungkapkan (1) Pendidikan agama berfungsi membentuk manusia Indonesia yang beriman dan bertakwa kepada Tuhan Yang Maha Esa serta berakhlak mulia dan mampu menjaga kedamaian dan kerukunan hubungan inter dan antarumat beragama. (2) Pendidikan agama bertujuan untuk berkembangnya kemampuan peserta didik dalam memahami, menghayati, dan mengamalkan nilai-nilai agama yang menyerasikan penguasaannya dalam ilmu pengetahuan, teknologi dan seni.

Sebagai konsekwensi dari adanya pelajaran agama tersebut, pemerintah menyediakan pengajar pelajaran agama sebagaimana dalam PP Nomor 55 tahun 2007 pada pasal 6 bahwa pendidik pendidikan agama pada satuan pendidikan yang diselenggarakan oleh pemerintah atau pemerintah daerah disediakan oleh pemerintah atau pemerintah daerah sesuai kewenangan masing-masing berdasarkan ketentuan peraturan perundang-undangan.

Kalau melihat uraian tersebut diatas, guru pendidikan agama Islam khususnya, mempunyai peranan yang sangat penting untuk menjadikan anak didik memiliki akhlak mulia dan mampu menjaga kedamaian dan kerukunan. Pada kenyataan di lapangan ternyata sebagian anak didik tidak sesuai dengan apa yang diharapkan. Oleh karena itu guru pendidikan agama Islam pada sekolah umum khususnya di SMP Kab. Ciamis perlu memiliki profesionalisme dalam pengabdiannya untuk mengarahkan anak didik kepada yang lebih baik. Salah satu wadah yang diharapkan dapat memupuk $r$ profesionalisme guru PAI di SMP adalah musyawarah guru mata pelajaran (MGMP) termasuk di dalamnya musyawarah guru Pendidikan Agama Islam (PAI)

Kalimat MGMP terdiri dari dua unsur kata yang bermakna, yaitu Musyawarah dan Guru Mata Pelajaran. Pengertian Musyawarah mencerminkan kegiatan dari, oleh dan untuk guru. Sedangkan Guru Mata Pelajaran adalah guru SMA Negeri maupun Swasta yang bertanggung jawab mengelola mata pelajaran yang ditetapkan di dalam kurikulum. MGMP merupakan suatu wadah bermusyawarahnya para guru mata pelajaran sejenis dalam suatu jenjang baik SMP atau SMA. Musyawarah Guru Mata Pelajaran (MGMP) ini juga merupakan suatu 
ISSN: 1829-6750 Inovasi Kurikulum, Agustus 2009, Thn. 6 . Vol 6 Nomor: 2

forum atau wadah kegiatan profesionalisme guru yang kegiatan di dalamnya dari oleh dan untuk guru. Hal ini seperti yang dikemukakan oleh Satori (1998: 28) bahwa: "Jalur lain yang sifatnya non struktural adalah pemanfaatan secara berhasil guna forum gugus mata pelajaran sejenis di sekolah yaitu MGMP. Wadah dari-oleh-untuk guru tersebut sangat strategis dimanfaatkan sebagai mekanisme andal dalam supervisi akademik".

MGMP ( Musyawarah Guru Mata Pelajaran), adalah wadah untuk pertemuan para guru mata pelajaran sekolah. Mulyasa (2006 : 236) mengemukakan bahwa MGMP merupakan organisasi atau wadah yang dapat meningkatkan profesionalisme dan kinerja guru. Lembaga ini dibentuk tidak hanya sebagai forum silaturahmi, tetapi juga sebagai forum untuk menampung berbagai permasalahan yang dihadapi guru di sekolah masing-masing sesuai dengan tugas dan tanggung jawab yang diembannya. Tujuan MGMP terutama adalah untuk meningkatkan kompetensi dan profesionalisme guru dalam rangka meningkatkan kualitas pendidikan. Lebih lanjut Mulyasa (2006) mengutarakan bahwa MGMP juga dapat menyusun dan mengevaluasi perkembangan kemajuan belajar. Melalui MGMP diharapkan semua kesulitan dan permasalahan yang dihadapi oleh guru dalam pembelajaran dapat dipecahkan, dan dapat diharapkan dapat meningkatkan mutu pendidikan di sekolah melalui peningkatan mutu pembelajaran (efective teaching).

Prinsip-prinsip dalam kegiatan MGMP yang tercantum dalam buku pedoman Penyelenggaraan Kegiatan MGMP yang diterbitkan oleh Direktorat Pendidikan Dasar dan Menengah Jakarta adalah :

1. Prinsip musyawarah MGMP merupakan wadah kegitan guru mata pelajaran sejenis yang secara bersama-sama memecahkan berbagai masalah yang dihadapi dalam pelaksanaan tugas sebagai pengajar mata pelajaran yang menjadi tanggungjawabnya. Pemecahan masalah dilakukan berdasarkan musyawarah dimana setiap anggota mempunyai kedudukan, peran dan kesempatan yang sama.

2. Prinsip dari guru, oleh guru dan untuk guru. Keterlibatan guru dalam kegiatn MGMP sangat diperlukan dan hasilnya dapat 
ISSN: 1829-6750 Inovasi Kurikulum, Agustus 2009, Thn. 6 . Vol 6 Nomor: 2

dijadikan sebagai pedoman pelaksanaan. Dalan hal ini penyelenggaraan kegiatan MGMP sangat ditentukan oleh keterrlibatan dan partisifasi aktif dari semua anggota tanpa terkecuali.

3. Prinsip Mandiri. Pada dasarnya kegiatn MGMP: dibentuk atas kebutuhan profesional guru untuk meningkatkan kemampuan dan keterampilan dalam melaksanakan tugas profesinya sebagai pengajar dan merupakan tuntutan individual dari setiap guru. Oleh karena itu kegiatan MGMP dilaksanakan secara mandiri dengan dukungan dari sekolah yang gurunya terlibat dalam MGMP

Berdasarkan prinsip-prinsip kegiatan MGMP, sesuai dengan buku pedoman penyelenggaraan MGMP (1993 : 6) maka pungsi dari kegiatan MGMP adalah sebagai motivator. Diharapkan dengan kegaitan MGMP dapat memberikan motivasi kepada guru-guru untuk meningkatkan kemampuan dan kemahiran mengajar sehingga dapat menunjang usaha peningkatan dan pemerataan mutu pendidikan, menunjang pemenuhan kebutuhan guru yang berkaitan dengan kegiatan belajar mengajar khususnya menyangkut materi pelajaran, metodologi, sistim evaluasi dan sarana penunjang, serta menyebarkan informasi tentang segala kebijakan yang berkaitan dengan usaha-usaha pembaharuan pendidikan dalam bidang kurikulum, metodologi, sistim evaluasi dan lain-lain. Sebagaimana tercantum dalam buku pedoman pelaksanaan MGMP SLTP Kota Bandung (2002 : 5) bahwa MGMP mempunyai fungsi sebagai berikut :

1. Wahana penyebar informasi mengenai kebijakan yang berkaitan dengan usaha-usaha pembaharuan pendidikan dalam bidang kurikulum, metodologi dan sistim evaluasi;

2. Wahana pengembang motivasi guru agar mengikuti kegiatan untuk meningkatkan kemampuan dan kemahiran dalam melaksanakan kegiatan belajar mengajar;

3. Sebagai penyebarluasan hasil penataran atau latihan kerja tingkat pusat ketingkat di bawahnya untuk diterapkan;

4. Sebagai sarana diskusi atau penampungan saran-saran, pendapat dari berbagai pihak yang relevan dalam rangka mengembangkan kemampuan 
ISSN: 1829-6750 Inovasi Kurikulum, Agustus 2009, Thn. 6 . Vol 6 Nomor: 2

profesional guru sekaligus meningkatkan kinerja MGMP dan MGP;

5. Sebagai sarana pengembang partisifsi seluruh anggota MGMP/MGP dalam meningkatkan kemampuan dalam pembuatan karya tulis dan kreatifitas lainnya.

Sesuai dengan fungsi dan kegiatan MGMP maka jenis kegiatan yang dilaksanakan adalah :

a. MGMP adalah mengembangkan kemampuan dan keterampilan guru untuk meningkatkan keberhasilan kegiatn belajar mengajarnya dengan melakukan usaha-usaha antara lain ; penguasaan kurikulum, penyusunan program semester, penyusunan progaram satuan pelajaran termasuk pengusaan dan pengembangan metode, penggunaan media pengajaran dan teknik evaluasi, Bahan / materi pelajaran;

b. Kegiatan yang termasuk perluasan wawasan, antara lain : mengadakan ceramah / diskusi, mengadakan seminar I lokakarya, program-program kompetensi / lomba untuk siswa dalam usaha meningkatkan penguasaan ilmu pengetahuan dan teknologi; c. Kegiatan penunjang lainnya, antara lain : mengadakan pelatihan, program peninjauan / pengamatan / widya wisata ke obyek-obyek yang relevan, dan memanfaatka media cetak dan media elektronika.

\section{Metode Penelitian}

Penelitian ini menggunakan metode deskriptif analisis kualitatif. Dikatakan deskriptif karena penelitian ini dilakukan dengan maksud untuk mendapatkan jawaban permasalahan yang diajukan secara apa adanya sekarang tanpa mempersoalkan keadaan sebelum ataupun sesudahnya, yaitu tentang kebutuhan program musyawarah guru mata pelajaran untuk meningkatkan profesionalisme guru (studi kasus pada Musyawarah Guru Mata Pelajaran Pendidikan Agama Islam SMP di Kab. Ciamis)

Penelitian ini tidak hanya berusaha mendeskripsikan secara mendalam (thick description) program MGMP PAI SMP di Kab. Ciamis yang sesuai dengan kebutuhan untuk meningkatkan profesionalisme guru, tetapi juga menganalisis perencanaan program MGMP, dan program MGMP PAI SMP di Kab. 
ISSN: 1829-6750 Inovasi Kurikulum, Agustus 2009, Thn. 6 . Vol 6 Nomor: 2

Ciamis yang dilakukan oleh pengurus MGMP maupun oleh guru dalam meningkatkan profesionalismenya. Karena itu penelitian ini menggunakan metode deskriptif analitik.

Metode yang digunakan dalam penelitian ini adalah studi kasus. Dengan metode ini peneliti dapat melakukan penelitian lebih mendalam tentang berbagai persoalan yang berkaitan dengan kebutuhan program MGMP PAI untuk

profesiomnalisme guru.

Sumber data penelitian ini adalah informan yang dipandang dapat memberikan data yang berhubungan dengan kebutuhan program musyawarah guru mata pelajaran pendidikian Agama Islam untuk meningkatkan profesionalisme guru. Secara garis besar adalah : (1) Para guru pendidikan agama Islam SMP di Kab. Ciamis peserta MGMP, (2) Pengurus MGMP pendidikan agama Islam SMP di Kab. Ciamis.

Dalam penelitian ini tidak ditentukan oleh banyaknya (jumlah) informan, tetapi yang dipentingkan adalah sampel dapat memberikan segenap informasi yang dibutuhkan secara mendalam sesuai dengan sasaran penelitian.

Data yang diperlukan dalam penelitian ini sesuai dengan fokus penelitian antara lain :

1. Perencanaan program MGMP PAI SMP untuk meningaktkan profesionalisme guru PAI SMP di Kab. Ciamis, meliputi data tentang bagaimana perencanaan program MGMP PAI SMP dalam hal: (a) komponen program perencanaan, (b) fungsi dan peranan perencanaan, dan (c) kelengkapan perencanaan program;

2. Kebutuhan program MGMP PAI SMP untuk meningkatkan profesionalisme gur PAI SMP di Kab. Ciamis, Meliputi data tentang kebutuhan guru dalam hal : (a) kebutuhan untuk mengembangkan kurikulum, (b) kebutuhan untuk meningkatkan keterampilan pengelolaan pembelajaran, (c) kebutuhan untuk meningkatkan kemampuan dalam menggunakan media pembelajaran, dan (d) kebutuhan untk meningkatkan kemampuan

dalam 
ISSN: 1829-6750 Inovasi Kurikulum, Agustus 2009, Thn. 6 . Vol 6 Nomor: 2

\author{
menggunakan evaluasi \\ pembelajaran.
}

\section{Program}

MGMP untuk meningkatkan profesionalisme guru PAI SMP di Kab. Ciamis, meliputi data tentang program MGMP PAI SMP di Kab. Ciamis, dalam hal ; (a) model program dan (b) penyususnan program

Prosedur pengumpulan data yang dilakukan adalah sebagai berikut : (1) tahap orientasi, (2) tahap eksplorasi, dan (3) tahap member check.

Data yang diperoleh melalui observasi, wawancara, dan studi dokumentasi, Adapun proses dan teknik pengumpulan data yang disebut diatas, dapat dijelaskan sebagai berikut :

Melalui observasi, selama penelitian dilakukan pengamatan secara langsung terhadap perencanaan program MGMP PAI SMP di Kab Ciamis. Semua aktivitas dalam program MGMP PAI SMP di Kab. Ciamis diamati secara seksama baik yang berkaitan dengan pengurus maupun yang berkaitan dengan Guru PAl. Bagaimana pengurus MGMP PAI SMP di Kab. Ciamis melakukan kegiatannya, mulai dari merencanakan program
MGMP PAI SMP, mengidentifikasi kebutuhan guru PAI SMP dan melihat program MGMP PAI SMP tersebut. Begitu juga dalam kegiatan observasi ini, peneliti mencermati beberapa hal, berkaitan dengan guru PAI SMP di Kab. Ciamis, mulai dari bagaimana guru PAI SMP mengikuti program MGMP PAI SMP, merencanakan program MGMP PAI SMP dan bagaimana keterlibatannya dalam memenuhi kebutuhan guru tersebut dalam program MGMP PAI SMP dalam meningkatkan profesionalismenya. Untuk mengatur dan mengontrol arah serta tujuan observasi, peneliti menyiapkan panduan observasi atau pengamatan yang sesuai dengan tujuan penelitian.

Wawancara dilakukan secara langsung dengan nara sumber sebagai responden utama, yaitu pengurus MGMP Pendidikan Agama Islam yang bertanggung jawab penuh terhadap kepengurusannya. Wawancara ini dilakukan tidak bersifat kaku atau mendikte, hal ini dimaksudkan untuk menghilangkan kekakuan dan manipulasi data dari pihak responden. Untuk kelancaran wawancara, peneliti sebelumnya telah mempersiapkan berupa panduan wawancara. 
ISSN: 1829-6750 Inovasi Kurikulum, Agustus 2009, Thn. 6 . Vol 6 Nomor: 2

Mengingat sebagai instrumen pengumpul data adalah peneliti itu sendiri yang dihadapkan langsung dengan responden, maka harus diciptakan suasana sedemikian rupa. Hal ini dapat dimaklumi agar responden berada dalam suasana yang wajar, artinya responden harus merasa dirinya sendiri, sehingga dapat memberi keterangan apa adanya. Data yang diperoleh dicatat sesuai dengan jenisnya. Selain mempersiapkan perlengkapan untuk mendapatkan data dari responden seperti tape recorder dan alat tulis, juga terlebih dahulu mengkompermasikan waktu wawancara.

Studi dokumentasi ini dilakukan untuk memperoleh data berupa keterangan atau informasi yang diperlukan melalui data tertulis baik yang bersifat akademis maupun yang bersifat administratif. Data hasil temuan ini kemudian diklarifikasi sesuai dengan jenis dan sekaligus dimungkinkan saling melengkapi antara data/ informasi dari hasil observasi dan wawancara sehingga ditemukan data yang utuh dan akurat. Data yang dikumpulkan melalui studi dokumentasi yaitu : kebutuhan program Musyawarah Guru Mata Pelajaran Pendidikan agama Islam, Keadaan Guru
Pendidikan Agama Islam SMP di Kab. Ciamis, dan lain-lain.

Analisis data yang digunakan dalam penelitian ini adalah analisis kualitatif. Analisis kualitatif adalah upaya penelaahan atas esensi, mencari makna di balik frekuensi dan variansi; analisis kualitatif memberikan peluang untuk berfikir divergen, horizontal : linear, dan hierarkhi, di samping berfir konvensional : linear, non linear Dalam penelitian ini, analisis data secara bertahap dilakukan pada tiap data yang telah terkumpul.

Proses analisis data penelitian ini selama penelitian berada dilapangan dengan jalan, mencoba untuk selekas mungkin menetapkan fokus penelitian sehingga peneliti jangan sampai bias oleh banyak hal lainnya yang kelihatan mungkin menarik. Peneliti harus berusaha mampu mendisiplinkan diri untuk tidak menggali semua hal yang kelihatan penting, padahal tidak ada hubungannya dengan fokus penelitian ini, yakni bertalian dengan program MGMP PAI SMP yang sesuai dengan kebutuhan untuk meningkatkan profesinlaisme guru.

Analisa data dalam penelitian ini dilakukan dengan mengikuti prosedur atau langkah-langkah 
ISSN: 1829-6750 Inovasi Kurikulum, Agustus 2009, Thn. 6 . Vol 6 Nomor: 2

seperti yang dikemukakan oleh Milles dan Huberman (1982:16-20) dan oleh Nasution (1988 : 129-130) yaitu reduksi data, display data, dan mengambil kesimpulan dan verifikasi.

Pengujian tingkat validitas data dalam studi kualitatif ini berpedoman pada konsep Nasution (1988) dan Muhadjir (1990) dengan mengutamakan kebermaknaan data sehingga mempunyai arti yang dapat dipercaya. Proses pengujian kepercayaan validasi penelitian kualitatif ditentukan oleh beberapa kriteria, yaitu : (1). Kredibilitas (Validitas Internal),

Transferabilitas (Validitas Eksternal), dan (3). Depentabilitas (Reliabilitas dan konfirmabilitas (objektivitas). (Nasution, 1988 : 114120).

\section{Hasil Penelitian dan Pembahasa}

Guru PAI yang profesional harus dapat pengetahuan, meningkatkan kerterampilan secara terus menerus, baik wawasan kehidupan sebagai arah dari perkembangan ilmu pengetahuan dan teknologi, kebijakan pemerintah yang harus diantisipasi juga perubahanperubahan yang harus diciptakannya sendiri dalam rangka meningkatkan kualitas pembelajaran.

Meningkatkan kemampuan profesional guru PAI melalui kegiatan MGMP merupakan cara yang paling mudah dan murah untuk merealisasikannya, dimana guruguru bidang studi sejenis berkumpul untuk memecahkan masalah yang dihadapinya pada kegiatan belajar mengajar di sekolahnya masingmasing dengan keputusan dan pertimbangan disesuaikan dengan situasi dan kemampuan sekolah. Dengan demikian maka kegiatan tersebut merupakan kesempatan yang baik untuk memperdalam dan memperluas materi pelajaran.

Keseriusan dan keaktifan Guru PAI mengikuti MGMP akan dapat meningkatkan kemampuan profesionalnya. Profesionalisme guru PAI merupakan modal utama untuk dapat melaksanakan tugasnya dengan baik dan mampu menyelesaikan berbagai permasalahan, baik masalah pribadi maupun masalah orang lain. Guru PAl yang melaksanakan tugasnya dengan baik sangat mendukung kearah peningkatan mutu pendidikan di sekolah. 
ISSN: 1829-6750 Inovasi Kurikulum, Agustus 2009, Thn. 6 . Vol 6 Nomor: 2

\section{Perencanaan Program MGMP PAI SMP di Kabupaten Ciamis}

Perencanaan program musyawarah guru mata pelajaran harus sesuai dan relevan dengan kondisi sekolah, keberadaan guru, sarana dan prasarana, waktu dan ketersediaan biaya, sehingga tujuan dapat dicapai dengan baik. Berkenaan dengan faktor-faktor yang mempengaruhi perencanaan program, maka perbedaan karakter peserta didik dan lingkungan sekolah, latar belakang pendidikan dan penguasaan pengetahuan serta wawasan tentang pendidikan agama Islam merupakan faktor yang harus diperhatiakan dalam membuat perencanaan. Hal ini dilakukan untuk mengurangi kesenjangan antara kenyataan dengan apa yang diharapkan.

Berdasarkan fungsi dan peranan perencanaan program, maka suatu perencanaan merupakan:

sebagai petunjuk dan arah kegiatan dalam mencapai tujuan musyawarah guru mata pelajaran pendidikan agama Islam, sebagai pola dasar dalam mengatur tugas dan wewenang bagi setiap unsur yang terlibat dalam kegiatan MGMP PAI, (3) Sebagai pedoman kerja bagi pengurus MGMP dan guru-guru PAI di SMP, (4) sebagai alat ukur efektif tidaknya suatu kegiatan MGMP, sehingga setiap saat diketahui ketepatan dan kelemahan yang ada, (5. untuk menghemat waktu, tenaga, alat-alat dan biaya.

Program MGMP sangat penting bagi kelancaran dan peningkatan kegiatan belajar-mengajar di sekolah dalam rangka menyampaikan materi pelajaran kepada siswa karena masalah kesulitan, kekurangan, kesalahan dalam melaksanakan kegiatan belajar mengajar selalu saja terjadi. Oleh karena itu dengan adanya pengimplementasian perencanaan program MGMP PAI SMP sangat membantu bagi setiap guru PAI. Perencanaan program selain membuat hal-hal yang sudah baku dan digariskan yang bersifat standar dan pokok bisa dilengkapi dengan faktor lain seperti lingkungan sekolah, karena lingkungan sekolah yang satu mungkin ada saja perbedaannya, kepribadian, ilmu dan wawasan guru agama itu sendiri, lingkungan masyarakat, keberadaan komite dan orang tua siswa, semua itu harus dipertimbangkan membuat perencanaan program, agar semua sekolah terakomodasi, agar 
ISSN: 1829-6750 Inovasi Kurikulum, Agustus 2009, Thn. 6 . Vol 6 Nomor: 2

progarm itu bisa dilaksanakan dalam setiap sekolah.

Secara umum perencanaan merupakan penyusunan langkahlangkah kegiatan yang akan dilaksanakan untuk mencapai tujuan yang telah ditetapkan. Suatu perencanaan dapat disusun berdasarkan jangka waktu tertentu yaitu jangka panjang, jangka menengah dan jangka pendek; menurut luas jangkauannya yaitu perencanaan makro dan perancanaan mikro; perencanaan menurut wewenang pembuatnya yaitu sentralisasi dan desentralisasi; dan menurut telaahnya yaitu perencanaan strategis dan perencanaan menejerial dan perencanaan operasional.

Perencanaan kegiatan MGMP PAI juga difokuskan pada upaya pengembangan kurikulum yang berkenaan dengan pemahaman kurikulum tingkat satuan pendidikan dan merupakan sasaran utama dalam program perencanaan musyawarah guru mata pelajaran dalam upaya mengembangkan kurikulum berdasarkan standar isi dan standar kompetensi lulusan yang dijabarkan menjadi program perencanaan pembelajaran dalam bentuk silabus dan rencana pelaksanaan pembelajaran. $\mathrm{Hal}$ tersebut dapat diwujudkan apabila fungsi perencanaan benar-benar diperhatikan oleh guru PAI dalam proses pembelajaran. Adapun fungsi perencanaan MGMP, sebagai berikut : (a) memberikan motivasi kepada para guru agar mengikuti setiap kegiatan belajar-mengajar di forum MGMP, (b) meningkatkan kemampuan dan kemahiran guru dalam melaksanakan kegiatan belajar-mengajar sehingga dapat menunjang usaha peningkatan dan pemerataan mutu pendidikan, (c) memberikan pelayanan konsultatif yang berkaitan dengan kegiatan belajar-mengajar, (d) menunjang pemenuhan kebutuhan guru yang berkaitan dengan kegiatan belajarmengajar, khususnya yang menyangkut materi pelajaran, metodologi, sistem evaluasi, dan sarana penunjang, dan (e) menyebarkan informasi tentang segala kebijakan yang berkaitan dengan usaha-usaha pembaharuan pendidikan dalam bidang kurikulum, metodologi, sistem evaluasi, dan lain-lain

\section{Kebutuhan Program MGMP PAI SMP di Kabupaten Ciamis}
a. Kebutuhan untuk
mengembangkan kurikulum. 
ISSN: 1829-6750 Inovasi Kurikulum, Agustus 2009, Thn. 6 . Vol 6 Nomor: 2

Mengembangkan

kurikulum dalam kegiatan

Musyawarah Guru Mata Pelajaran Pendidikan Agama Islam merupakan kebutuhan program. Kurikulum yang dikembangkan adalah kurikulum mata pelajaran pendidikan agama Islam di SMP. Pengembangan kurikulum ini merupakan tugas profesional guru yang berkaitan dengan kemampuan guru dalam menjabarkan standar kompetensi dan kompetensi dasar ke dalam komponen-komponen yang ada dalam silabus dan rencana pelaksanaan pembelajaran.

Dalam mengembangkan Kurikulum Tingkat Satuan Pendidikan (KTSP), guru harus memperhatikan prinsipprinsip pengembangan KTSP, yaitu: a). berpusat pada potensi, perkembangan, kebutuhan, dan kepentingan peserta didik dan lingkungannya, b). beragam dan terpadu, c). tanggap terhadap perkembangan ilmu pengetahuan, teknologi dan seni, d). relevan dengan kebutuhan kehidupan, e). menyeluruh

dan berkesinambungan, f). belajar sepanjang hayat, g). seimbang antara kepentingan nasional dan kepentingan daerah. Ketika mengembangkan kurikulum, guru PAI memperhatikan prinsip-prinsip tersebut, dipastikan ia lebih mudah menjabarkan standar kompetensi dan kompetensi dasar ke dalam silabus.

Hasil penelitian menunjukan bahwa program Musyawarah Guru Mata Pelajaran Pendidikan Agama Islam di Kabupaten Ciamis dilaksanakan untuk mengembangkan kurikulum tingkat satuan pendidikan, yang dilakukan secara bersama-sama oleh guru PAI Sekolah Menengah Pertama. Guru PAI berupaya menjabarkan standar kompetensi dan kompetensi dasar ke dalam silabus dan selanjutnya menjabarkan silabus ke dalam rencana pelaksanaan pembelajaran. Peran guru PAI dalam mengembangkan kurikulum adalah sangat penting, karena guru sebagai perencana, pelaksana dan pengembang kurikulum.

Berdasarkan hal diatas, maka kegiatan Musyawarah Guru Mata Pelajaran yang dilakukan oleh guru PAI di Kabupaten Ciamis pada dasarnya adalah kegiatan pengembangan kurikulum. Guru secara bersama-sama mengembangkan standar isi yang telah ditetapkan oleh BSNP dan dibimbing dan dipandu oleh nara 
ISSN: 1829-6750 Inovasi Kurikulum, Agustus 2009, Thn. 6 . Vol 6 Nomor: 2

sumber sehingga program MGMP yang dilaksanakan dalam rangka meningkatkan kemampuan profesionalisme guru PAI di Kabupaten Ciamis.

\section{b. Kebutuhan untuk meningkat- kan keterampilan pengelolaan pembelajaran}

Pengelolaan pembelajaran yang dilakukan oleh guru pendidikan agama Islam merupakan keterampilan yang harus dimiliki guru dalam menciptakan dan memelihara kondisi belajar yang optimal. Secara umum pengelolaan kelas yang dilakukan oleh guru harus memperhatikan hal-hal sebagai berikut: (a) menciptakan kondisi belajar yang optimal, (b) menunjukan Sikap Tanggap, (c) memusatkan Perhatian. (d) memberi Petunjuk dan Tujuan yang jelas, dan (e) memberi Teguran dan Penguatan.

Berkenaan dengan pengelolaan kelas, tentang bagaimana guru mengelola isi atau materi pelajaran. Pengelolaan Isi/materi pelajaran yang dilakukan oleh guru harus disiapkan dan direncanakan dalam silabus dan sistem penilaian yang dibuat oleh guru. Dari silabus yang dibuat oleh guru akan tergambar jenis dan satuan pendidikan, jenjang pendidikan dan tingkatan kelas serta semester, standar kompetensi lulusan permata pelajaran yang harus dicapai siswa, kompetensi pembelajaran setiap materi pokok pembelajaran, indikator dan hasil belajar siswa, perencanaan pengalaman belajar dan pengembangan kecakapan hidup, skenario pembelajaran, penilaian serta sumber, alat dan media pembelajran yang akan digunakan. Penentuan materi pembelajaran Pendidikan Agama Islam (PAI) yang dilakukan oleh guru dalam kegiatan Musyawarah Guru Mata Pelajaran, haruslah memperhatikan dan mempertimbangkan tingkat perkembangan fisik, intelektual, emosional, sosial dan spiritual siswa, kegunaan bagi peserta didik, struktur keilmuan, kedalaman dan keluasan materi, relevansi dengan kebutuhan siswa dan tuntutan lingkungan serta alokasi waktu.

Berkenaan dengan kebutuhan untuk meningkatkan pengelolaan pembelajaran, maka kegiatan MGMP yang meliputi dua program yaitu program umum dan program khusus. Program umum berupa kebijakan-kebijakan Departemen Agama dalam meningkatkan kualitas pendidikan dalam bentuk school based management hal ini 
ISSN: 1829-6750 Inovasi Kurikulum, Agustus 2009, Thn. 6 . Vol 6 Nomor: 2

diberikan guna menambah wawasan dan pengetahuan bagi guru mengingat pendidikan dewasa ini sedang membenahi diri dan menyempurnakannya sehubungan dengan adanya perubahan sistem pemerintahan sentralisasi menjadi desentralisasi yang tentunya mempengaruhi pada sistem pendidikan nasional kita, sehingga juga mempengaruhi kebijakankebijakan pendidikan. Dengan demikian kegiatan MGMP mencoba mengantisipasi perubahan tersebut dengan menyampaikan informasiinformasi kepada guru-guru PAI agar para guru mempersiapkan kemampuannya dalam mengatasi segala perubahan yang terjadi. Program yang berikutnya yaitu program khusus, berupa pengembangan kurikulum tingkat satuan pendidikan dalam bentuk program perencanaan berupa penyusunan silabus dan rencana pelaksanaan keterampilan pembelajaran, pengelolaan pembelajaran, penggunaan median dan evaluasi pembelajaran.

Program khusus ini merupakan program akademis yang diberikan dalam rangka menambah kemampuan guru dalam mengajar sehingga dapat meningkatkan kualitas pembelajaran Pendidikan
Agama Islam sesuai dengan kurikulum yang berlaku. Pendidikan saat ini sedang mengembangkan kurikulum tingkat satuan pendidikan (KTSP), sehingga guru harus memahami secara komperhensif mengenai kurikulum tersebut dan mengimplementasikannya secara bertanggung jawab di kelas. Selain itu, penelitian ini, juga mengungkap bahwa para guru PAI memperoleh informasi tentang pengetahuan dan keterampilan masih sangat terbatas. Pengetahuan yang diperoleh oleh guru PAI hanya pada materi yang diharuskan oleh kurikulum yang untuk pelajaran PAI semuanya telah temuat dalam buku paket. Secara jelasnya hal yang biasa dilakukan oleh para guru peserta MGMP yang berhubungan dengan penguasaan materi PAI dan kurikulum yaitu meliputi : (a) mengikuti bahan kurikulum PAI, (b) mengkaji isi buku-buku teks PAI, (c) melaksanakan kegiatan-kegiatan yang disarankan dalam kurikulum PAI yang bersangkutan, dan (d) mempelajari ilmu yang relevan (baru sebagian guru).

Berdasarkan hal di atas dapat dikatakan bahwa para guru PAI masih belum memahami tugas pokok guru (10 kompetensi guru) yang harus diketahui dan 
ISSN: 1829-6750 Inovasi Kurikulum, Agustus 2009, Thn. 6 . Vol 6 Nomor: 2

dilaksanakannya untuk menjadi guru yang profesional. Sebagai seorang guru seharusnya memahami betul tentang materi yang akan diberikan kepada siswanya. Apakah materi tersebut memenuhi kebutuhan siswa, apakah kurikulumnya sudah sesuai dengan tuntutan kebutuhan masyarakat, bagaimanakah hubungan antara ilmu sehingga salingberkontribusi

untuk mengembangkan segala potensi yang ada pada diri siswanya, dan sebagainya

\section{c. Kebutuhan Untuk Meningkat- kan Kemampuan dalam Menggunakan Media Pembelajaran.}

Kebutuhan terhadap penggunaan media pembelajaran yang digunakan oleh guru-guru PAI, sebagaimana yang dikemukakan oleh Responden D, bahwa media pembelajaran sangat penting dalam membantu pencapaian tujuan pembelajaran atau penguasaan kompetensi dasar oleh peserta didik. Pemanfaatan media pembelajaran untuk membantu kelancaran proses belajar mengajar PAI berupa media cetak, media audio visual dan media elektronik dalam penggunaannya disesuaikan dengan tujuan, materi pembelajaran serta karakteristik mata pelajaran $\mathrm{PAI}$.

Penggunaan media pembelajaran oleh guru PAI dalam prakteknya disesuaikan dengan kompetensi dasar yang harus dicapai, materi pembelajaran, kemampuan guru menggunakan media serta sesuai dengan fasilitas yang tersedia pada satuan pendidikan masing-masing. Untuk lebih meningkatkan lagi kemampuan guru PAl dalam menggunakan media dan sumber pembelajaran lainnya, diperlukan upaya yang sungguh-sungguh dari penyelenggara kegiatan MGMP untuk memberikan informasi pengetahuan dan keterampilan yang dapat meningkatkan kemampuan tersebut. Selama ini materi MGMP PAl yang menunjang kearah itu masih dirasakan kurang. Meningkatnya kemampuan guru PAI dalam menggunakan media dan sumber pembelajaran diharapkan dapat merubah cara pembelajaran konvensional dimana guru sebagai satu-satunya sumber belajar di kelas. Wina Sanjaya (2006 : 169) mengemukakan bahwa media pembelajaran memiliki nilai praktis yaitu, 1) media dapat mengatasi keterbatasan pengalaman yang dimiliki siswa, 2) media dapat mengatasi batas ruang kelas, 3) 
ISSN: 1829-6750 Inovasi Kurikulum, Agustus 2009, Thn. 6 . Vol 6 Nomor: 2

media dapat memungkinkan terjadinya interaksi langsung antara peserta dengan lingkungan, 4) media dapat menghasilkan keseragaman pengamatan, 5) media dapat menanamkan konsep dasar yang benar, nyata dan tepat, 6) media dapat membangkitkan motivasi dan merangsang peserta untuk belajar dengan baik, 7) media dapat membangkitkan keinginan dan minat baru, 8) media dapat mengontrol kecepatan belajar siswa, 9) media dapat memberikan pengalaman yang menyeluruh dari hal-hal yang konkret sampai yang abstrak.

\section{d. Kebutuhan Untuk meningkat- kan Kemampuan dalam Evaluasi Pembelajaran}

Evalusi pembelajaran merupakan komponen yang tak terpisahkan dari komponen-komponen lain seperi tujuan, materi, dan indikator pembelajaran. Kemampuan dan pengetahuan guru pendidikan agama Islam (PAI) dalam evaluasi sangat menentukan terhadap ketepatan dalam menilai kemampuan belajar siswa. Hal ini dapat dipelajari dan diperdalam pada kegiatan Musyawartah Guru Mata Pelajaran (MGMP), sehingga guru PAI dapat melaksanakan kegiatan evaluasi dengan baik sesuai dengan pedoman dan ketentuan-ketentuan dalam mengevaluasi kegiatan pembelajaran.

Jenis penilaian kelas yang dikembangkan pada KTSP, meliputi penilaian tertulis, unjuk kerja, produk dan portofolio. Penilaian tertulis merupakan tes yang dilaksanakan dalam bentuk tertulis. Penilaian tertulis digunakan pada waktu terbatas dan kondisi tertentu. Penilaian unjuk kerja (performance) adalah penilaian yang digunakan untuk kompetensi yang berhubungan dengan praktek. Penerapannya dalam mata pelajaran pendidikan agama Islam khususnya berkaitan dengan praktek ibadah. Penilaian unjuk kerja dilakukan berdasarkan pengamatan penilai dengan memperhatikan aktivitas yang dilakukan oleh siswa. Aspek yang dinilai meliputi unjuk kerja, tingkah laku serta interaksi antar siswa. Penilaian unjuk kerja menuntut siswa untuk mendemontrasikan pengetahuan dan keterampilannya dalam berbagai macam konteks sesuai dengan kriteria yang diinginkan. Penilaian unjuk kerja lebih tepat dipergunakan untuk kemampuan siswa dalam dalam 
ISSN: 1829-6750 Inovasi Kurikulum, Agustus 2009, Thn. 6 . Vol 6 Nomor: 2

berpidato, melakukan khutbah jum'at, berdoa, melantunkan ayat suci Al-Quran, pembacaan puisi, diskusi, pemecahan masalah dalam suatu kelompok, partisipasi siswa dalam diskusi kelompok kecil.

Penilaian produk merupakan penilaian yang digunakan untuk menilai kemampuan siswa dalam menghasilkan suatu karya teknologi dan seni seperti kaligrtafi, pakaian muslim dan lain sebagainya. Penilaian portofolio adalah kumpulan pekerjaan seseorang yang merupakan suatu kumpulan atau berkas bahan pilihan yang dapat memberi informasi baagi suatu penilaian. Portofolio dibidang pendidikan dikaitkan dengan peserta belajar atau siswa berarti kumpulan dari tugas-tugas peserta didik yang dapat memberi informasi bagi suatu penilaian kinerja yang objektif. Berkas tersebut berisi pekerjaaan siswa, dokumen atau gambar, yang menunjukan apa yang dapat dilakukan seseorang dalam lingkungan dan suasana kerja yang alamiah, yang sesungguhnya, bukan dalam lingkungan dan suasana kerja yang dibuat-buat.

Pada umumnya pemahaman guru PAI tentang penilaian atau evaluasi hanyalah sebagai akhir dari proses belajar mengajar, dimana siswa memperoleh nilai sebagai ukuran dari kemampuan yang telah dicapainya. Tindak lanjut dari hasil evaluasi hanya dilakukan guru PAI pada ulangan harian saja. Hal ini disebabkan karena pada ulangan umum akhir semester, soal tes tidak dibuat oleh guru secara perorangan tetapi disuplai dari tingkat rayon. Pembuat soalnya memang para guru PAI secara bersama-sama, tetapi tidak semua guru dilibatkan. Jadi banyak guru PAI yang setiap ulangan umum tidak pernah membuat soal, cukup tinggal memeriksa hasilnya saja. Kondisi ini berdampak pada aktivitas guru dalam melakukan analisis soal. Banyak guru PAI yang malas untuk melakukan analisa terhadap soal yang berkaitan dengan pelajaran yang di empunya. Program yang terdapat dalam kegiatan MGMP berkaitan dengan informasi pengetahuan tentang cara menganalisis butir soal banyak diperoleh, tetapi tidak diaplikasikan. Alasannya bahwa hasil dari analisis itu sendiri kurang dirasakan manfaatnya, karena pada ulangan umum selanjutnya merekapun tidak akan membuat soal lagi.

Dilihat dari validitas soalnya, ulangan umum yang diselenggarakn 
ISSN: 1829-6750 Inovasi Kurikulum, Agustus 2009, Thn. 6 . Vol 6 Nomor: 2

dengan soal yang sama pada seluruh sekolah yang berada di lingkungan salah satu komisariat, tidak memiliki validitas yang tinggi. Hal tersebut mengingat gaya dan cara serta metode mengajar setiap guru pada setiap sekolah berbedabeda walaupun pada mata pelajaran yang sejenis. Demikian juga pada waktu perumusan TIK oleh setiap guru tentu banyak yang berbeda, ditambah dengan perbedaan dalam penggunaan buku paket yang menjadi pegangannya. Sehingga kadang-kadang ada soal yang keluar dalam ulangan umum, padahal oleh gurunya belum atau tidak dibelajarkan.

\section{Program MGMP PAI SMP di Kabupaten Ciamis.}

Berdasarkan hasil penelitian menunjukan bahwa program workshop Musyawarah Guru Mata Pelajaran Pendidikan Agama Islam SMP Kabupaten Ciamis, terdiri dari dua jenis program. Pertama program umum berkenaan dengan informasi kebijakan Departeman Agama Kabupaten Ciamiss dan pembinaan sumber daya manusianya. Kedua program khusus yang difokuskan kepada kegiatan sosialisasi dan pengembangan kurukulum tingkat satuan pendidikan, membuat sialabus dan rencana pelaksanaa pembelajaran, model dan media pembelajaran serta penilaian berbasis kelas.

Berdasarkan program umum, materinya hanya sebatas kebijakankebijakan Departemen Agama dalam bidang pendidikan yang berkenaan dengan kegiatan pengembangan kurikulum oleh guru PAl. Hal ini tentu saja memberikan wawasan tentang landasan dalam melaksanakan kegiatan MGMP, sehingga kegiatan yang dilakukan oleh guru PAI SMP Ciamis baik secara langsung ,maupun tidak langsung merupakan program Departemen Agama yang dijalankan di daerah.

Untuk tataran KTSP, secara umum (mayoritas) sudah tersosialisasikan namun itupun masih dalam (proses) pemahaman. Salah seoraang pengurus MGMP, mengemukakan dalam program MGMP, kaitannya dengan KTSP telah dilaksanakan workshop kurikulum tingkat satuan pendidikan PAI SMP. Workshop yang merupakan model program MGMP PAI SMP sesuai dengan perencanaan, atas dasar musyawarah antara penguruas dengan guru PAI SMP, dengan 
ISSN: 1829-6750 Inovasi Kurikulum, Agustus 2009, Thn. 6 . Vol 6 Nomor: 2

materi-materi workshop yang meliputi tiga program yaitu : program Umum terdiri dari : informasi kebijakan Dinas Pendidikan Kabupaten Ciamis, informasi kebijakan Depag Kabupaten Ciamis, dan pembinaan SDM dilingkungan Depag, Begitu juga materi yang berkaitan dengan Model dan media pembelajaran, Penilaian berbasis kelas, Praktek menyusun silabus, Praktek menyusun RPP, Presentasi hasil diskusi.

Kedua program tersebut sangat berguna bagi guru PAl yang berkeinginan untuk meningkatkan kualitas pembelajaran PAI di sekolahnya dan merupakan tuntutan bagi guru untuk melaksanakannya di sekolah sesuai dengan tuntutan kurikulum yang berlaku. Oleh karen itu program tersebut tidak hanya dilaksanakan di MGMP tingkat Kabupaten juga diberikan pada MGMP tingkat Kecamatan, agar wawasan tersebut secara merata dimiliki oleh seluruh guru PAI di Kabupaten Ciamis. Penentuan materi pelatihan ditentukan atas dasar musyawarah antara pengurus MGMP PAI SMP dengan guru, kepala sekolah, pengawas dan Dinas Pendidikan dan Depag. Dengan demikian sejak awal sudah terlihat kerjasama yang baik antara pihak-pihak terkait. Peserta pelatihan MGMP PAI direkrut melalui tes. Jadi hanya guru-guru PAI SMP yang bersedia dan berkeinginan kuat untuk meningkatkan kualitas pembelajaran PAI yang menjadi peserta pelatihan. Agar mereka bertanggungjawab

mengimplementasikannya dalam kegiatan belajar mengajar serta dapat mensosialisasikannya di tingkat Kecamatan maupun di tingkat sekolah. Dari jumlah guru PAI SMP Negeri yang ada di Kabupaten Ciamis berjumlah 120 dari 51 sekolah hanya 50 orang guru yang menjadi peserta. dalam hal ini jelas sekali proses perekrutannya.

Selain itu pertemuan rutin di luar hari efektif, yang ditetapkan setaip hari sabtu dengan penjadwalan kegiatan yang jelas dimana setiap minggu pertama dan keempat dipergunakan untuk kegiatan MGMP tingkat sekolah dan minggu ke dua untuk tingkat Komisariat serta minggu ke tiga untuk tingkat Kabupaten, tidak membuka peluang guru untuk alasan tidak menghadirinya. Kegiatan MGMP dapat berjalan dengan lancar karena dukungan dari berbagai pihak terkait yang mengharapakan profesioinalisme guru PAI di Kabupaten Ciamis. 
ISSN: 1829-6750 Inovasi Kurikulum, Agustus 2009, Thn. 6 . Vol 6 Nomor: 2

Kegiatan MGMP pun berjalan pada tingkat sekolah dimana guru-guru PAl secara rutin membicarakan masalah yang berkaitan dengan materi pelajaran baik metode maupun pemahaman dan pendalaman terhadap materi pelajaran yang akan diberikan atau masalalah lain yang menyangkut pelajaran PAI secara keseluruhan atau informasi lainnya.

Kegiatan membuat rencana pelaksanaan pembelajaran melalui program MGMP PAI diawali dengan pemahaman arti dan tujuan serta menguasai secara teoritis dan praktis terhadap unsur-unsur yang terdapat dalam RPP tersebut. Rencana pelaksanaan pembelajaran berisi garis besar (outline) apa yang akan dikerjakan oleh guru dan peserta didik selama proses pembelajaran, baik untuk satu kali pertemuan maupun meliputi beberpa kali pertemuan. Guru yang belum berpengalaman pada umumnya memerlukan perencanaan yang lebih rinci dibandingkan dengan guru yang sudah berpengalaman.

Identifikasi kompetensi merupakan langkah pertama yang harus dilakukan dalam pengembangan RPP, karena beberapa materi standar mungkin memiliki lebih dari satu kompetensi dasar. Di samping itu, perlu ditetapkan pula pokus kompetensi yang diharapkan dari peserta didik sebagai akhir pembelajaran. Kompetensi ini juga akan menjadi pedoman bagi guru dalam menentukan materi standar yang akan digunakan dan pendekatan pembelajaran yang tepat untuk membentuk kompetensi peserta didik.

\section{Simpulan}

\section{Perencanaan program MGMP PAI SMP}

Perencanaan program Musyawarah Guru Mata Pelajaran Pendidikan Agama Islam SMP di Kabupaten Ciamis, sudah sesuai dengan pedoman penyusunan MGMP PAI SMP, baik pedoman yang dibuat oleh Direktorat Jendral Pendidikan dan Kebudayaan maupun pedoman yang dibut oleh Departemen Agama. Pada dasarnya penyusun program MGMP PAI di Kabupaten Ciamis relevan dengan apa yang ada/ kondisi di sekolah secara umum, karena pada umumnya sekolah mempunyai banyak kesamaan. Kemudian acuan yang pokok seperti kurikulum yang bersifat nasional yang kemudian dikembangkan 
ISSN: 1829-6750 Inovasi Kurikulum, Agustus 2009, Thn. 6 . Vol 6 Nomor: 2

dalam bentuk KTSP juga menjadi bahan pertimbangan yang masuk kedalam program MGMP PAI. Begitu juga kalender pendidikan yang berlaku, juga materi-materi yang secara mutlak harus dibahas dan disampaikan kepada siswa juga menjadi bahan penyusunan program MGMP PAI.

\section{Kebutuhan Program MGMP PAI SMP di Kabupaten Ciamis}

\section{a. Kebutuhan untuk mengem- bangkan kurikulum}

Pengembangan Kurikulum Tingkat satuan Pendidikan merupakan kebutuhan program MGMP PAI SMP untuk meningkatkan profersionalisme guru. Kurikulum Tingkat Satuan Pendidika (KTSP) merupakan program yang akan disampaikan kepada siswa pada masing-masing sekolah yang sifatnya lokal dan mandiri. Didalamnya berisi materi-materi yang relevan dengan kebutuhan siswa, sekolah, lingkungan masyarakat termasuk orang tua siswa dan komite sekolah itu sendiri. Walau demikian tetap mengacu kepada aspek-aspek dasar yang sifatnya Nasional. Oleh karena itu KTSP harus dikembangkan oleh sekolah yang bersangkutan termasuk komitenya. Dan supaya lebih mengena kepada arah dan sasaran yang lebih tepat, maka guru PAI harus lebih berperan dalam pengembangan KTSP ini terutama menyangkut pelajaran PAl. Berdasatkan hal itu maka guru PAI harus memiliki kemampuan, wawasan, mampu mengembangkan visi, misi, dan strategi sesuai mata pelajaran PAI. Mampu menguasai materi PAI, mampu melihat kondisi sosial masyarakat dan kondisi sekolah itu sendiri.

\section{b. Meningkatkan keterampilan pengelolaan pembelajaran}

Dalam pengelolaan pembelajaran, terutama profesionalisme guru dalam mengelola kelas harus dimiliki oleh guru PAI. Kerterampilam dalam pengelolaan kelas ini, diantaranya adalah kemampuan untuk menyampaikan materi yang sesuai, mengkondisikan siswa/ anak didiknya, memilih metode pembelajaran yang tepat dan sesuai dengan kondisi dan situasi, mengatur waktu atau alokasi waktu, menghidupkan/memotivasi

siwa/peserta didik agar lebih hidup di dalam kelas, memberikan kesempatan bagi anak didik untuk bertanya dan menjawab. 
ISSN: 1829-6750 Inovasi Kurikulum, Agustus 2009, Thn. 6 . Vol 6 Nomor: 2

\section{c. Kebutuhan untuk meningkat- kan kemampauan dalam menggunakan media pembelajaan.}

Penggunaan media pembelajaran oleh guru PAI dalam prakteknya disesuaikan dengan kompetensi dasar yang harus dicapai, materi pembelajaran, kemampuan guru menggunakan media serta sesuai dengan fasilitas yang tersedia pada satuan pendidikan masing-masing. Untuk lebih meningkatkan lagi kemampuan guru PAI dalam menggunakan media dan sumber pembelajaran lainnya, diperlukan upaya yang sungguh-sungguh dari penyelenggara kegiatan MGMP untuk memberikan informasi pengetahuan dan keterampilan yang dapat meningkatkan kemampuan tersebut.

\section{d. Kebutuhan untuk mening- katkan kemampuan dalam mengguanakan evaluasi pembelajaran}

Kemampuan dan pengetahuan guru pendidikan agama Islam (PAl), tentang evaluasi sangat menentukan terhadap ketepatan dalam menilai kemampuan belajar siswa. Hal ini dapat dipelajari dan diperdalam pada kegiatan
Musyawartah Guru Mata Pelajaran (MGMP), sehingga guru PAl dapat melaksanakan kegiatan evaluasi dengan baik sesuai dengan pedoman dan ketentuan-ketentuan dalam mengevaluasi kegiatan pembelajaran. Dalam konteks KTSP, maka kegiatan penilaian yang dilakukan oleh guru PAI adalah penilaian berbasis kelas. Penilaian berbasis kelas merupakan suatu proses pengumpulan, pelaporan, dan penggunaan informasi tentang hasil belajar siswa dengan menerapkan prinsip-prinsip penilaian, pelaksanaan berkelanjutan, bukti-bukti autentik, akurat, dan konsisten. Penilaian berbasis kelas mengidentifikasi pencapaian kompetensi dan hasil belajar yang dikemukakan melalui pernyataan yang jelas tentang standar yang harus dan telah dicapai disertai dengan peta kemajuan belajar siswa dan pelaporan.

\section{Program MGMP PAI SMP di Kabupaten Ciamis}

Program Musyawarah Guru Mata Pelajaran merupakan kegiatan dalam pengembangan kurikulum dan merupakan salah satu upaya untuk meningkatkan profesionalisme guru PAI SMP di Kabupaten

Ciamis,

yang 
ISSN: 1829-6750 Inovasi Kurikulum, Agustus 2009, Thn. 6 . Vol 6 Nomor: 2

dilaksanakan melalui kegiatan MGMP dengan tujuan meningkatkan wawasan, pemahaman dan pengetahuan tentang standar isi, standar kompetensi lulusan dan pedoman pelaksanaannya. Kegiatan pengembangan kurikulum yang dilakukan melalui wadah workshop MGMP merupakan suatu kegiatan yang penting dan strategis dalam bidang pendidikan, karena kurikulum sebagai rancangan pendidikan memiliki kedudukan strategis dalam seluruh kegiatan pendidikan

\section{DAFTAR PUSTAKA}

Achasius. (1988) Pengembangan Kurikulum. Jakarta : Departemen Pendidikan dan Kebudayaan. Direktorat Jendral Pendidikan Tinggi. Proyek Pengembangan Lembaga Pendidika Tenaga Kependidikan.

Abdul Madjid. (2007). Perencanaan Pembelajaran

Mengembangkan Standar Kompetensi Guru. Bandung : Rosda Karya.
Arikunto. (1990). Dasar-Dasar Evaluasi Pendidikan. Jakarta : Bumi Aksara

Bogdan, Robert \& Biklen, SK. (1992) Qualitative Research for Educations an Introduction to Theory and Method. Boston : Allyn and Bacon Inc.

Danim. (2002). Inovasi Pendidikan Dalam Upaya Peningkatan Profesionalisme Tenaga Kependidikan.Bandung Pustaka Setia

Creswell, John W. (1998). Qualitative Inquiry and Research Design. Thousand Oaks California : Sage Publ.

Departemen Pendidikan dan Kebudayaan.

Pedoman Penyelenggaraan MGMP Seluruh Indonesia. Jakarta : Direktorat Pendidikan Dasar Menengah Umum.

Dinas Pendidikan Kota Bandung. (2002). Pedoman Pelaksanaan Musyawarah Guru Mata Pelajaran (MGMP) SLTP dan Musyawarah Guru Pembimbing (MGP) SLTP Kota Bandung. Bandung : PT. Sarana Panca Karya Nusa 
ISSN: 1829-6750 Inovasi Kurikulum, Agustus 2009, Thn. 6 . Vol 6 Nomor: 2

Direktorat Jenderal Pendidikan Islam. (2008). Pedoman Musyawarah Guru Mata Pelajaran Pendidikan Agama Islam Sekolah Menengah Pertama (MGMP PAI SMP). Jakarta : Departemen Agama RI

Direktorart Jendral Kelembagaan Agama Islam. (2004). Standar Kompetensi Pendidikan Agama Islam Pada Sekolah Umum dan Madrasah. Jakarta : Departemen Agama RI.

Djuju Sudjana. (2006). Evaluasi Program Pendidikan Luar Sekolah Untuk Pendidikan Nonformal dan Pengembanagn Sumber Daya Manusia.

Bandung :Rosdakarya

Teknik Pembelajaran Partisipatif. Bandung :Fallah Production

(1992). Pengantar Manajemen Pendidikan Luar Sekolah. Bandung : Nusantara Press

Diraktorat Jendral Pendidikan Dasar dan Menengah. (1998). Pedoman Penyelenggaraan
Musyawarah Guru Mata Pelajaran (MGMP). Jakarta : Proyak Perluasan dan Peningkatan Mutu SLTP.

Dinas Pendidikan Kota bandung (2002). Panduan Pelaksanaan Musyawarah Guru Mata Pelajaran (MGMP) SLTP dan Musyawarah Guru Pembimbing (MGP) SLTP Kota Bandung. Bandung : Sarana Panca karya Nusa

Klein. M. Frances (1989). Curriculum Reform in The Elementary School Creating Your own agenda. New York and London. Teacher Collage Columbia University.

Hasibuan. (2003). Manajemen Dasar, Pengertian, dan masalah. Jakarta : Bumi Aksara

Lembaga Administrasi Negara. (1997). Bahan Materi Pendidikan dan Pelatihan Prajabatan Pegawai Negeri Sipil Golongan III. Jakarta.

Lincoln, Yvonna S. \& Guba Egon G. (1985), Naturalistic Inquiry. Beverly Hills : Sage Publications, Inc 
ISSN: 1829-6750 Inovasi Kurikulum, Agustus 2009, Thn. 6 . Vol 6 Nomor: 2

Manap Somantri

Penelusuran

Rendahnya

melanjutkan dari SD ke SLTP

dan Implikasinya Bagi

Pemantapan Rencana

Pelaksanaan Wajib Belajar

SLTP di Kab. Bogor (Tesis).

Bandung

Program

Pascasarjana IKIP Bandung

Miles, Matthew B and Heberman, A.Michael. (1984). Alih bahasa Tjetjep Rohendi Rohidi (1992). Analisa Data Kualitatif. Jakarta : UI

Mulyasa. (2006). Kurikulum Tingkat Satuan Pendidikan Sebuah Panduan Praktis. Bandung : Rosdakarya

Nana

Syaodih.

(2002).Pengembangan

Kurikulum Teori dan Praktek.

Bandung : Rosdakarya

(2004). Landasan

Psikologi Proses Pendidikan.

Bandung : Rosdakarya

Nasution. (1996). Metode Penelitian

Naturalistik Kualitatif. Bandung

: Tarsito
Oemar Hamalik. (2006). Manajemen

Pengembangan Kurikulum.

Bandung : Rosdakarya

(2001). Proses

Belajar Mengajar. Jakarta :

Bumi Aksara

Pendidikan (Perwujudan

Dalam Sistim Pendidikan

Nasional. Bandung : Universitas Pendidikan Indonesia

(2000).

Pendidikan Guru Berdasarkan

Pendekatan Sistem. Bandung.

(2006). Inovasi

Pendidikan ( Perwujudan dalam Sistim Pendidikan Nasional). Bandung : Pasca Sarjana

Said Hamid. (1988). Evaluasi Kurikulum. Jakarta : Departemen Pendidikan dan Kebudayaan Direktorat Jendral Pendidikan Tinggi Proyek Pengembangan lembaga Pendidikan Tenaga Kependidika.

Suedarminto.

(1991).

Pengembangan Kurikulum 
ISSN: 1829-6750 Inovasi Kurikulum, Agustus 2009, Thn. 6. Vol 6 Nomor: 2

dan Bahan Belajar I. Jakarta : Universitas Terbuka

Supriadi Dedi (1998). Mengangkat

Citra dan Martabat Guru.

Yogyakarta : Adicita Karya

Nusa

Uzer. (1992). Menjadi Guru Profesional. Bandung : Rosdakarya

Widodo. ( 1994). Pengembangan Kurikulum dan bahan Belajar II. Jakarta : Universitas Terbuka

Wina Sanjaya. (2007). Strategi Pembelajaran Berorientasi Standar Proses Pendidikan. Jakarta : Kencana Prenada Media Group 